$\begin{array}{ll}\text { Volume } & : 04 \\ \text { Nomor } & : 03 \\ \text { Bulan } & : \text { September } \\ \text { Tahun } & : 2018 \\ \text { http } & : \text { //ejurnal.pps.ung.ac.id/index.php/AKSARA/index }\end{array}$

\title{
Pengaruh Bauran Promosi Terhadap Keputusan Nasabah dalam Pembelian Polis Asuransi di PT. Asuransi Umum Bumiputera Muda 1967 Cabang Gorontalo
}

\author{
Djoko Lesmana Radji, Dwi Sufrirachmat Putera Nalole \\ Universitas Negeri Gorontalo \\ djokolesmanaradji@gmail.com
}

\begin{abstract}
ABSTRAK
Penelitian ini bertujuan untuk mengetahui seberapa besar pengaruh bauran promosi terhadap keputusan pembelian dengan cara menyebar kuesioner kepada responden yang telah memenuhi standar sampel yang telah ditentukan sehingga data dalam penelitian ini merupakan data primer. Pengumpulan data diperoleh dari hasil observasi, kuisioner dan dokumentasi. Metode penelitian yang digunakan adalah metode penelitian kuantitatif. Penetapan sampel yang digunakan dalam penelitian adalah non-probability sampling. Dan metode yang digunakan untuk pengumpulan sampel adalah metode Accidental sampling. Kemudian analisis data menggunakan regresi linear sederhana dengan bantuan program SPSS 21. Hasil Penelitian menunjukan bahwa terdapat pengaruh yang signifikan dari bauran promosi terhadap keputusan nasabah dalam pembelian polis asuransi Pada PT. Asuransi Umum Bumiputera Muda 1967 Cabang Gorontalo. Hasil R Square adalah sebesar 0,481. Nilai ini menunjukan bahwa sebesar 48,1\% variabilitas keputusan nasabah dalam pembelian polis asuransi nasabah pada PT. Asuransi Umum Bumiputera Muda 1967 Cabang Gorontalo dapat dijelaskan oleh bauran promosi yang dilakukan oleh perusahaan, sedangkan sisanya sebesar 51,9\% dapat dijelaskan oleh variabel lain yang tidak diteliti dalam penelitian ini. Variabel lain tersebut yakni Produk, Price (harga), Place (lokasi), People (orang), Phisical Evidence dan Proses.
\end{abstract}

\section{Kata Kunci: Bauran Promosi, Keputusan Nasabah}

\section{PENDAHULUAN}

Persaingan yang begitu ketat sekarang ini membuat perusahaanperusahaan harus mampu memainkan strategi pemasaran yang handal dan mampu menarik minat konsumen sehingga mampu memenangkan pasar. Produk yang memiliki kualitas yang baik dengan diferensiasi yang juga baik akan menjadi produk yang kemungkinan besar memiliki konsumen loyal. Dengan memahami bagaimana perilaku konsumen akan memberi sumbangsih bagi perusahaan untuk merumuskan strategi pemasaran yang nantinya akan diimplementasikan dalam memperkenalkan dan mempromosikan produk mereka ke pasar. Artinya ketika suatu produk hendak diproduksi, jauh sebelumnya telah diketahui apa yang menjadi kebutuhan dan keinginan konsumen.

Penelitian ini dilaksanakan pada perusahaan yang bergerak dalam bidang jasa asuransi. Pengertian asuransi menurut Pasal 1 ayat 1 Undang-Undang Nomor 40 Tahun 2014 Tentang Perasuransian bahwa asuransi adalah perjanjian antara dua pihak, yaitu perusahaan asuransi dan pemegang polis, yangmenjadi dasar bagi 


$\begin{array}{ll}\text { Volume } & : 04 \\ \text { Nomor } & : 03 \\ \text { Bulan } & : \text { September } \\ \text { Tahun } & : 2018 \\ \text { http } & : / / \text { jurnal.pps.ung.ac.id/index.php/AKSARA/index }\end{array}$

penerimaan premi oleh perusahaan asuransi sebagai imbalan untuk tanggung jawab hukum kepada pihak ketiga yang mungkin diderita tertanggung Perusahaan asuransi sebagai perusahaan jasa, menjual jasa kepada pelanggan pada satu sisi, sedangkan pada sisi lain, perusahaan asuransi adalah sebagai investor dari tabungan masyarakat kepada investasi yang produktif, sebagaimana perusahaan pada umumnya perusahaan asuransi membutuhkan dua perusahaan mengenai usahanya.

Salah satu perusahaan asuransi di Gorontalo yakni PT. Asuransi Umum Bumiputera Muda 1967 Cabang Gorontalo, dimana perusahan asuransi ini menjual berbagai macam produkpolis asuransi. Berbagai produk tersebut diantaranya Produk Perorangan dan Produk Korporasi serta Produk Khusus. Pemilihan objek penelitian pada PT. Asuransi Umum Bumiputera Muda 1967 Cabang Gorontalo didasarkan pada masalah dimana masalah yang terjadi menyangkut keputusan pembelian. Masalah tersebut diantaranya mengenai pengenalan masalah kebutuhan yang masih kurang, hal tersebut dikerenakan kurangnya informasi mengenai asuransi dari PT. Asuransi Umum Bumiputera Muda 1967 Cabang Gorontalo yang diketahui oleh masyarakat.

Berdasarkan survei yang dilakukan peneliti bahwa perusahan asuransi ini umumnya telah menggunakan strategi pemasaran untuk memasarkan produknya, namun strategi yang dilakukan oleh perusahan asuransi ini masih kurang optimal. Dari hasil wawancara yang lakukan oleh peneliti terhadap beberapa konsumen dimana produk yang dijual di perusahan asuransi ini masih kurang dipahami oleh masyrakat luas. Terbatasnya pengetahuan masyrakat tentang asuransi menjadi suatu kendala terhambatnya perkembangan industri asuransi di Indonesia, hanya masyarakat kelas menengah ke atas yang sudah mengerti mengenai asuransi, sedangkan masyarakat kelas bawah banyak yang tidak tahu mengenai asuransi.

\section{KAJIAN TEORI \\ Pengertian Promosi}

Kegiatan promosi dalam perusahaan merupakan bagian terpenting disamping variabel lainnya yaitu produk, harga, dan lokasi perusahaan. Promosi merupakan salah satu faktor penentu keberhasilan program pemasaran. Menurut Kotler dan Armstrong (2008: 59) promosi adalah kegiatan menginformasikan atau menyampaikan keunggulan suatu produk dan untuk meyakinkan konsumen untuk membeli produk tersebut. Stanton (2008 : 171) memberikan definisi promosi adalah salah satu bauran pemasaran yang didayagunakan untuk memberitahukan, membujuk dan mengingatkan tentang produk perusahaan.

\section{Pengertian Bauran Promosi}

Menurut Kotler dan Armstrong (2008:116), "Bauran promosi (promotion mix) juga disebut bauran komunikasi pemasaran (marketing communication mix) perusahaan merupakan paduan spesifik hubungan masyarakat, iklan, promosi penjualan, penjualan personal, dan sarana pemasaran langsung yang digunakan perusahaan untuk mengkomunikasikan nilai pelanggan secara persuasif dan membangun hubungan pelanggan". 


$\begin{array}{ll}\text { Volume } & : 04 \\ \text { Nomor } & : 03 \\ \text { Bulan } & : \text { September } \\ \text { Tahun } & : 2018 \\ \text { http } & : / / \text { jurnal.pps.ung.ac.id/index.php/AKSARA/index }\end{array}$

Promotion mix atau bauran promosi adalah kombinasi strategi yang paling baik dari unsur-unsur promosi yang digunakan untuk mencapai tujuan perusahaan. Selanjutnya Rismiati dan Suratno dalam bukunya pemasaran barang dan jasa, (2001:255), pada dasarnya variable-variabel dalam promotion mix ada empat yaitu: periklanan (advertising), penjualan personal (personal selling), hubungan masyarakat (public relations), dan promosi penjualan (sales promotion).

\section{Tujuan Promosi}

Menurut Buchari Alma (2013:181) dalam bukunya manajemen pemasaran dan pemasaran jasa mengatakan bahwa tujuan promosi penjualan adalah sebagai berikut:

1. Menarik perhatian para pembeli baru.

2. Memberi hadiah atau penghargaan kepada konsumen atau pelanggan lama.

3. Meningkatkan daya pembelian ulang dari konsumen lama.

4. Mempopulerkan merek atau meningkatkan loyalitas.

5. Meningkatkan volume penjualan jangka pendek dalam rangka memperluas market share jangka panjang.

\section{METODE PENELITIAN}

Desain penelitian ini menggunakan prosedur-prosedur yang memungkinkan peneliti dapat menguji hipotesis penelitian untuk mencapai kesimpulan-kesimpulan yang valid mengenai rumusan masalah yang diteliti. Penelitian ini menggunakan metode penelitian deskriptif. Penelitian deskriftif adalah studi untuk menemukan fakta dengan interprestasi yang tepat (Nazir :2005). Desain penelitian ini tergambar dari kerangka desain penelitian seperti yang terdapat pada gambar di bawah ini:

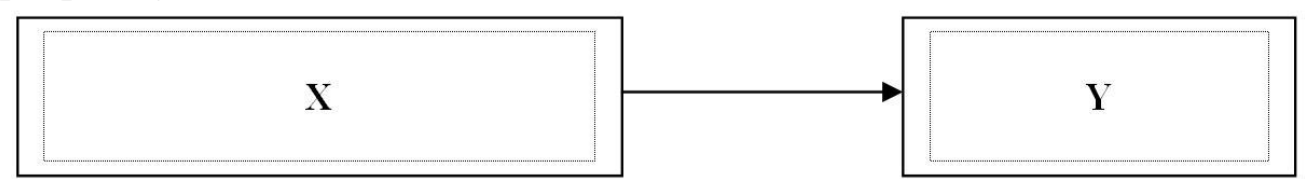

Keterangan :

$\mathrm{X}=$ Bauran Promosi

$\mathrm{Y}=$ Keputusan Pembelian

Variabel adalah suatu atribut atau sifat atau nilai dari orang, objek, atau kegiatan yang mempunyai variasi tertentu yang ditetapkan oleh peneliti untuk dipelajari dan ditarik kesimpulannya (Sugiyono, 2007:2). Penelitian ini menggunakan dua variabel yaitu :

a. Variabel independent

Variabel dependen adalah variabel yang menjadi pusat perhatian utama peneliti. Hakekat sebuah masalah mudah terlihat dengan mengenali berbagai variabel dependent yang digunakan dalam sebuah model. Variabilitas dari atau atas faktor inilah yang berusaha untuk dijelaskan oleh seorang peneliti. Dalam penelitian ini yang menjadi variabel independen adalah yaitu bauran promosi.

b. Variabel dependent

Variabel dependen yang dilambangkan dengan (Y) adalah variabel yang dipengaruhi oleh variabel independent $(\mathrm{X})$, baik yang pengaruhnya positif 


$\begin{array}{ll}\text { Volume } & : 04 \\ \text { Nomor } & : 03 \\ \text { Bulan } & : \text { September } \\ \text { Tahun } & : 2018 \\ \text { http } & : / / \text { jurnal.pps.ung.ac.id/index.php/AKSARA/index }\end{array}$

maupun yang pengaruhnya negatif.Variabel dependent dalam penelitian ini adalah keputusan pembelian konsumen.

\section{A. Populasi, Sampel dan Teknik Penentuan Sampel}

a. Populasi

Penulis menetapkan bahwa yang menjadi populasi dalam penelitian ini adalah seluruh nasabah yang ada pada PT. Asuransi Umum Bumiputera Muda 1967 Cabang Gorontalo. Hal ini mengacu pada pendapat Arikunto (2013:173) Populasi adalah "Totalitas semua nilai yang mungkin untuk menghitung hasil atau pengukuran mengenai karakteristik tertentu dari semua anggota kumpulan yang lengkap dan jelas yang ingin dipelajari sifat-sifatnya. Dalam kaitannya dengan penelitian ini, maka keseluruhan karakteristik yang menjadi populasi dalam penelitian ini adalah para nasabah yang ada di PT. Asuransi Umum Bumiputera Muda 1967 Cabang Gorontalo berjumlah 6123 orang.

b. Sampel

Sampel dalam penelitian ini adalah nasabah yang menggunakan polis asuransi di PT. Asuransi Umum Bumiputera Muda 1967 Cabang Gorontalo 2013 sampai dengan 2015. Besar sampel dalam dalam penelitian ini dengan menggunakan rumus Slovin (Sevilla et. al, 2006) sebagai berikut:

$$
\begin{aligned}
& \text { Dimana: } \\
& \text { n : ukuran sampel } \\
& \mathrm{N} \text { : ukuran populasi } \\
& \text { e : Nilai kritis (batas ketelitian) yang diinginkan (persen } \\
& \text { kelonggaran ketelitian karena kesalahan pengambilan sampel } \\
& \text { populasi), yaitu } 10 \% \text {, Jika tingkat kesalahan yang diinginkan (e) }
\end{aligned}
$$

Dalam penelitian ini, metode penelitian sampel yang digunakan adalah metode pengambilan sampel Accidental sampling atau convenience sampling, yaitu pengambilan sampel berdasarkan kebetulan, siapa saja yang kebetulan bertemu, dapat digunakan sebagai sampel dipandang orang yang ditemui tersebut cocok sebagai sumber data.

c. Teknik Pengumpulan Data

Untuk memperoleh data dari responden yang akan diteliti, maka penulis menggunakan beberapa teknik pengumpulan data (Arikunto, 2013:196) sebagai berikut:

1. Observasi, merupakan teknik pengumpulan data secara langsung kepada objek yang diteliti atau responden dalam rangka untuk memperkuat keabsahan data peneliti.

2. Angket, adalah menjadi teknik utama dalam pengumpulan data yakni dengan cara menyediakan sejumlah pertanyaan atau pernyataan yang akan dijawab oleh responden yang telah ditentukan, pertanyaanpertanyaan dimaksud tetap mengacu pada indikator-indikator yang 
telah ditentukan pada variabel penelitian ini. Dalam hal ini adalah semua konsumen yang ada di PT. Asuransi Umum Bumiputera Muda 1967 Cabang Gorontalo.

3. Dokumentasi yakni semua data yang bersumber dari lokasi penelitian dalam bentuk tertulis maupun tercetak, sebagai pelengkap data-data dalam penelitian ini.

Analisis data merupakan salah satu tahap kegiatan penelitian berupa proses penyusunan dan pengolahan data guna menafsirkan data yang telah diperoleh dari lapangan. Sugiyono (2007 : 169) menjelaskan, Analisis data merupakan kegiatan setelah data dari seluruh responden atau sumber data lain terkumpul. Kegiatan dalam menganalisis data adalah mengelompokkan data berdasarkan variabel dari seluruh responden, menyajikan data tiap variabel yang diteliti, melakukan perhitungan untuk untuk menjawab rumusan masalah, dan melakukan perhitungan untuk menguji hipotesis yang telah diajukan.

Analisis yang dilakukan dengan menginterprestasikan data yang diperoleh dari kuesioner kemudian membuat kesimpulan yang disajikan dengan susunan yang sistematis. Analisis dari tanggapan responden terhadap butir-butir pernyataan dari variabel penelitian menggunakan perbandingan antara skor aktual dengan skor ideal dengan rumus sebagai berikut:

Keterangan:

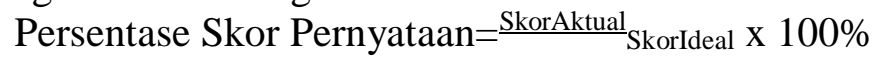

a. Skor Aktual adalah skor yang diperoleh dari jawaban seluruh responden atas kusioner yang telah diajukan.

b. Skor ideal adalah skor maksimum atau skor tertinggi yang diperoleh jika semua responden memilih jawaban dengan skor tertinggi.

\section{Uji Validitas}

Uji validitas dilakukan dengan mengkorelasikan masing-masing pernyataan dengan jumlah skor untuk masingmasing variabel. Teknik korelasi yang digunakan adalah teknik korelasi pearson. Untuk mempercepat dan mempermudah penelitian ini pengujian validitas dilakukan dengan bantuan komputer dengan menggunakan software SPSS 16.0 for windows dengan metode korelasi pearson.

Dalam pengujian validitas menggunakan software SPSS 16.0 (Statistical Product and Service Solutions). Pengambilan keputusan berdasarkan nilai $\mathrm{p}$ value/nilai signifikasi kurang dari 0,05 (5 persen) maka item pertanyaan tersebut dinyatakan valid dansebaliknya jika nilai $\mathrm{p}$ value atau signifikasi sama dengan atau lebih dari 0,05 (5persen) dinilai tidak valid.

\section{Uji Reliabilitas}

Menurut Sugiyono (2007:3) reliabilitas adalah "derajat konsistensi/keajegan data dalam interval waktu tertentu." Berdasarkan definisi diatas, Yang dimaksud dengan reliabilitas adalah pengukuran untuk suatu gejala. Semakin tinggi reliabilitas suatu alat ukur, maka semakin stabil alat tersebut untuk digunakan. alat Ukur dikatakan reliable (handal) kalau dipergunakan untuk mengukur 


$\begin{array}{ll}\text { Volume } & : 04 \\ \text { Nomor } & : 03 \\ \text { Bulan } & : \text { September } \\ \text { Tahun } & : 2018 \\ \text { http } & : / / \text { jurnal.pps.ung.ac.id/index.php/AKSARA/index }\end{array}$

berulangkali dalam kondisi yang relatif sama, akan menghasilkan data yang sama atau sedikit variasi.

\section{Konversi Data}

Dalam analisis regresi biasanya terdapat proses konversi data dari data skala ordinal (jenis data kualitataif) menjadi skala interval (jenis data kuantitatif) merupakan salah satu syarat yang harus dipenuhi dalam pengolahan data statistik parametrik. Data ordinal yang dikonversi menjadi data interval merupakan data penelitian yang dikumpulkan dengan cara penyebaran kusioner yang jawabannya menggunakan skala likert.

\section{Uji Normalitas}

Menurut Ghozali (2005:110) "uji normalitas bertujuan untuk menguji apakah dalam model regresi, variable pengganggu atau residual memiliki distribusi normal". Cara yang dapat digunakan untuk menguji apakah variabel pengganggu atau residual memiliki distribusi normal adalah dengan melakukan uji Kolmogorov-Smirnov terhadap model yang diuji dengan taraf signifikan $5 \%$. Kriteria pengambilan keputusan adalah apabila nilai signifikansi atau probabilitas $\geq 0.05$, maka residual memiliki distribusi normal dan apabila nilai signifikansi atau probabilitas $\leq 0.05$, maka residual tidak memiliki distribusi normal.

\section{Uji T}

Digunakan untuk mengetahui pengujian tingkat signifikansi pengaruh masing-masing variabel bebas terhadap variabel terikat dengan menggunakan uji t dengan langkah-langkah sebagai berikut:

1. Menentukan rumusan hipotesis nihil (Ho) dan hipotesis alternatif $(\mathrm{H} \alpha)$ :

Ho $: b_{1}=b_{2}=b_{3}=b_{4}=0$

Berarti tidak terdapat pengaruh yang signifikan antara variabel bebas terhadap variabel terikat.

$\mathrm{H} \alpha: \mathrm{b}_{1} \neq \mathrm{b}_{2} \neq \mathrm{b}_{3} \neq \mathrm{b}_{4} \neq 0$

Berarti terdapat pengaruh yang signifikan antara variabel bebas terhadap variabel terikat.

2. Menentukan level of significance $(\alpha)=5 \%$

3. Kriteria pengujian :

a. Jika $-\mathrm{t}$ tabel $\leq \mathrm{t}_{\text {hitung }} \leq+\mathrm{t}_{\text {tabel }}$ maka Ho diterima dan Ha ditolak,

b. Jika $t_{\text {hitung }} \leq-t_{\text {tabel }}$ atau $t_{\text {hitung }}>+t_{\text {tabel }}$ maka Ho ditolak dan Ha diterima.

(Subagyo dan Djarwanto, 2005: 268)

4. Penghitungan nilai $\mathrm{t}$

5. Kesimpulan, yaitu dengan membandingkan antara nilai $t_{\text {hitung }}$ dengan nilai $\mathrm{t}_{\text {tabel}}$, untuk menentukan Ho diterima atau ditolak.

\section{Koefisien Determinasi}

Untuk mengetahui berapa besar pengaruh variabel bebas terhadap variabel terikat yang ditujukan dengan presentasi. Nilai koefisien determinasi adalah antara 0 dan 1 yaitu, $0 \leq \mathrm{R}^{2} \leq 1$.Jika nilai koefisien determinasi kecil maka dapat 


$\begin{array}{ll}\text { Volume } & : 04 \\ \text { Nomor } & : 03 \\ \text { Bulan } & : \text { September } \\ \text { Tahun } & : 2018 \\ \text { http } & : \text { //ejurnal.pps.ung.ac.id/index.php/AKSARA/index }\end{array}$

diartikan bahwa kemampuan variabel-variabel bebas dalam menjelaskan variabel terikat sangat terbatas. Adapun rumus yang digunakan sebagai berikut :

(Mustofa, 2000: 136)

$$
R^{2}=\frac{b_{1} \sum X_{1} Y+b_{2} \sum X_{2} Y+b_{3} \sum X_{3} Y+b_{4} \sum X_{4} Y}{\sum Y^{2}}
$$

Keterangan:

$\mathrm{R}^{2}$ : koefisien determinasi

$\mathrm{b}_{1}, \mathrm{~b}_{2}, \mathrm{~b}_{3}, \mathrm{~b}_{4}$ : koefisien regresi

$\mathrm{X}$ : variabel independen

Y : variabel dependen

\section{HASIL PENELITIAN DAN PEMBAHASAN \\ Hasil Penelitian}

Penelitian ini dilaksanakan pada nasabah PT. Asuransi Umum Bumiputera Muda 1967 Cabang Gorontalo dengan cara menyebar angket/kusioner penelitian kepada responden yang memenuhi standar sampel yang ditentukan oleh peneliti sebelumnya. Data penelitian yang digunakan dalam penelitian ini merupakan data primer yang diperoleh dengan menggunakan daftar pernyataan (kuisioner) yang telah disebarkan langsung. Jumlah responden yang menjadi subjek penelitian sebanyak 99 responden yang memenuhi standar sampel penelitian. Kusioner disebarkan kemudian ditunggu oleh peneliti sehingga kusioner yang kembali sebanyak 99 kusioner. Tingkat pengembalian kuisioner (response rate) dan dapat digunakan (respon use) sebesar 100\%, dihitung dari presentase jumlah kuisioner yang kembali (99 kuisioner) dibagi total yang dikirim (99 kuisioner).

\section{a. Teтиап Uтит}

Nasabah memiliki preferensi pembelian polis asuransi yang baik, dalam hal ini keputusan nasabah dalam pembelian polis asuransi tersebut telah sesuai dengan suatu proses pengambilan keputusan yang diawali dengan identifikasi kebutuhan, evaluasi alternatif hingga sikap nasabah pasca pembelian. Keputusan pembelian tersebut terjadi karena adanya promosi yang agresif dari PT. Asuransi Umum Bumiputera Muda 1967 Cabang Gorontalo.

\section{b. Temuan Khusus}

Ditemukan bahwa tingkat kepercayaan $95 \%$ terdapat pengaruh yang signifikan dari bauran promosi terhadap keputusan nasabah dalam pembelian polis asuransi Pada PT. Asuransi Umum Bumiputera Muda 1967 Cabang Gorontalo. Untuk itu perlunya bagi PT. Asuransi Umum Bumiputera Muda 1967 Cabang Gorontalo untuk melakukan kegiatan promosi yang agresif dalam rangka untuk meningkatkan keputusan nasabah dalam pembelian polis asuransi Pada PT. Asuransi Umum Bumiputera Muda 1967 Cabang Gorontalo.

\section{Pembahasan}

Keputusan nasabah menjadi nasabah polis asuransi atau dalam hal ini dianalogikan sebagai keputusan pembelian merupakan suatu hal yang penting untuk diperhatikan karena hal ini tentu akan menjadi suatu pertimbangan bagaimana suatu strategi pemasaran yang akan dilakukan oleh perusahaan berikutnya. Keberhasilan perusahaan dalam mempengaruhi konsumen dalam 


$\begin{array}{ll}\text { Volume } & : 04 \\ \text { Nomor } & : 03 \\ \text { Bulan } & : \text { September } \\ \text { Tahun } & : 2018 \\ \text { http } & : / / \text { jurnal.pps.ung.ac.id/index.php/AKSARA/index }\end{array}$

keputusan pembelian sangat didukung melalui upaya membangun komunikasi kepada konsumen dengan membangun merek kepada konsumen dengan strategi pemasaran, serta melakukan inovasi untuk varians- varians baru pada suatu produk. Proses pengambilan keputusan pembelian yang rumit seringkali melibatkan beberapa keputusan. Suatu keputusan melibatkan pilihan diantara dua atau lebih alternatif tindakan.

Pada implementasinya setiap perusahaan yang ada tidak hanya fokus menggunakan satu atau dua dimensi bauran promosi saja, akan tetapi mereka selalu menggunakan kombinasi dari semua dimensi bauran promosi yang ada. Hal ini mengindikasikan bahwa antara satu dimensi bauran promosi dengan yang lainnya saling mendukung dan menyempurnakan. Sehingga perlunya bagi perusahaan untuk peningkatan bauran promosi terutama dalam aspek penjualan lansung yang menggunakan media sosial yang lebih menarik bagi nasabah. Sehingga hal ini akan berdampak pada keputusan nasabah untuk menjadi pengguna jasa asuransi PT. Asuransi Umum Bumiputera Muda 1967 Cabang Gorontalo

\section{SIMPULAN}

Berdasarkan hasil penelitian dan pembahasan di atas, maka dapat ditarik simpulan bahwa bahwa terdapat pengaruh yang signifikan dari bauran promosi terhadap keputusan nasabah dalam pembelian polis asuransi Pada PT. Asuransi Umum Bumiputera Muda 1967 Cabang Gorontalo. Koefisien regresi dengan arah postif menunjukan terdapat pengaruh yang positif bauran promosi terhadap keputusan nasabah dalam pembelian polis asuransi Pada PT. Asuransi Umum Bumiputera Muda 1967 Cabang Gorontalo.

\section{REFERENSI}

Arikunto, Suharsimi. 2013. Prosedur Penelitian Suatu Pendekatan Praktik. Jakarta : Rineka Cipta.

Buchari Alma. 2013. Manajemen Pemasaran dan Pemasaran Jasa Bandung, Alfabeta,

Rismiati.E. dan Ig. Bondan Suratno. 2001, Pemasaran Barang dan Jasa. Cetakan Pertama, Penerbit : Kanisius, Yogyakarta Catur E, Rismiati dan Ig, Bondan Suratno. 2001. Pemasaran Barang dan Jasa, cetakan pertama, Yogyakarta

Kotler Phlip., \& Gary Amstrong, 2008. Manajemen Pemasaran, Edisi Milenium diterjemahkan Benyamin Molan, Jakarta : PT. Prenhallindo.

Stanton, Wilian. J, 2008. Prinsip Pemasaran, Yogyakarta : Erlangga.

Sugiyono. 2011. Metode Penelitian Kuantitatif, kualitatif dan R\&D. Bandung: Alfabeta. Sugiyono. 2007. Metode Penelitian Kuantitatif Kualitatif dan $R \& D$. Bandung: Alfabeta

Sevilla, Consuelo G. et al. 2006. Pengantar Metode Penelitian. Jakarta : UI Press. Subagyo, Pangestu dan Djarwanto Ps. 2005. Statistik Induktif. Edisi 5. BPFE : Yogyakarta.

Selva temalagi dan Hengky latan. 2012. Analisis Multivariate Tehnik dan Aplikasi Menggunakan Program IBM SPSS 20.0. ALFABETA : Bandung

240 AKSARA Jurnal Ilmu Pendidikan Nonformal 